\title{
O LEGADO DE PAULO FREIRE À ONDA NEOCONSERVADORA: RESISTÊNCIA NA PRÁXIS
}

\author{
THE LEGACY OF PAULO FREIRE AND THE NEOCONSERVATIVE \\ WAVE: RESISTANCE IN PRAXIS
}

\author{
Nara Vieira Ramos \\ Doutora, Universidade Federal de Santa Maria - UFSM \\ Santa Maria, RS - Brasil \\ naravr@terra.com.br \\ (i) Maria Rita Py Dutra \\ Doutora, Universidade Federal de Santa Maria - UFSM \\ Santa Maria, RS - Brasil \\ mrpy54@gmail.com
}

\begin{abstract}
Resumo: O objetivo deste estudo é refletir sobre o legado de Paulo Freire e os processos possíveis de resistência e permanência a partir da educação popular, no enfrentamento à onda neoconservadora. Tem-se como questão de pesquisa como o legado de Paulo Freire poderá contribuir no arrefecimento da atual onda neoconservadora que atinge a sociedade brasileira, em especial o campo da educação? Trata-se de uma análise predominantemente teórica que busca dialogar com os campos político, econômico e social, dando ênfase à educação. No referencial teórico dialogamos com Freire $(1967,1980,1983)$, Bobbio, Matteucci \& Pasquino (1998), Mounk (2019), Apple (2004), entre outros. Ao aprofundarmos essa literatura destacamos três dimensões para compreender o atual momento em que vivemos e destacar possíveis caminhos para a resistência a partir da educação: a trajetória de Freire na construção do inédito viável; a onda neoconservadora na contemporaneidade e a práxis necessária para enfrentar os desafios de uma realidade opressora. Apontamos como possíveis caminhos aprofundar estudos e práticas a partir do legado Freireano, reinventando-o em um processo contínuo de ação-reflexão-ação em busca do sonho na construção da resistência.
\end{abstract}

Palavras Chave: Educação popular. Esperança. Neoconservadorismo. Práxis. Resistência.

\begin{abstract}
The aim of this study is to reflect on Paulo Freire's legacy and the possible processes of resistance and permanence from popular education, in what concerns the confrontation with the neoconservative movement. It has as its research question the ways how the legacy of Freire can contribute to the undermining of the current neoconservative wave that hits the Brazilian society, especially in the field of education. It is a predominantly theoretical analysis seeking dialogue with the political, economic and social fields, with emphasis on education. As theoretical references we dialogue with Freire (1967, 1980, 1983), Bobbio, Matteucci \& Pasquino (1998), Mounk (2019), Apple (2004), among others. As we deepen in this literature, we highlight three dimensions to understand the current moment we are living, and highlight possible paths for a resistance based in education: Freire's trajectory in the construction of the viable novelty; the neoconservative wave in contemporary times and the praxis needed to face the challenges of an oppressive reality. We also point out some possible ways to deepen studies and practices from the Freire legacy, reinventing it in a continuous process of action-reflection-action in search of the dream of building resistance.
\end{abstract}

Keywords: Popular education. Hope. Neoconservatism. Praxis. Resistance.

Para citar - (ABNT NBR 6023:2018)

RAMOS, Nara Vieira; DUTRA, Maria Rita Py. O legado de Paulo Freire à onda neoconservadora: resistência na práxis. Eccos - Revista Cientifica, São Paulo, n. 55, p. 1-19, e15775, out./dez. 2020. Disponível em: https://doi.org/10.5585/eccos.n55.15775. 


\section{Introdução}

Para as autoras participar dos eventos de celebração dos 50 Anos da obra Pedagogia do Oprimido foi uma grata oportunidade de revisitar Paulo Freire, sua vida, sua obra, seus ensinamentos e ao mesmo tempo, honrar sua memória. Num período em que Freire sofreu uma execração pública de parte do novo governo do Brasil, eleito em 2018, retomamos o grande mestre, em busca das sementes geradoras de tamanho ódio e medo.

A trajetória de vida de Paulo Freire foi marcada por tais ataques, tanto é que na Ditadura de 1964, foi obrigado a exilar-se, primeiramente no Chile, partindo depois para a Europa. Os anos de exílio serviram para que ele consolidasse suas teses e fosse reconhecido mundialmente como um dos três teóricos da educação mais consultados. Freire retorna ao Brasil junto com outros anistiados políticos e vai atuar na Pontifícia Universidade Católica de São Paulo PUC/SP e na Universidade de Campinas - Unicamp, com alta produção de livros, como também de militância política.

Com o Golpe impetrado contra a presidenta Dilma Rousseff, os apoiadores do golpe voltam-se contra a Educação, condenando a obra de Paulo Freire e acusando seus seguidores de comunistas. Quinze anos após sua morte, o cenário político atual é preocupante, mas os educadores progressistas que beberam em Freire, em especial os que adotam uma metodologia de educação popular, estão atentos, sem descartarmos a possibilidade de revivermos 10 de maio de 1933, quando na Alemanha, por ordem do regime nazista, montanhas de livros foram queimados.

O presente artigo tem por objetivo refletir sobre o legado de Paulo Freire e os processos possíveis de resistência a partir da educação popular no enfrentamento à onda neoconservadora. Tem-se como questão de pesquisa, como o legado de Paulo Freire poderá contribuir no arrefecimento da atual onda neoconservadora que atinge a sociedade brasileira, em especial o campo da educação? Organizamos em três dimensões: na primeira, trajetória de Paulo Freire na construção do inédito viável; na segunda, a onda neoconservadora na contemporaneidade e na terceira, a práxis necessária para enfrentar os desafios de uma realidade opressora. Trata-se de uma análise predominantemente teórica que busca dialogar com os campos político, econômico e social, dando ênfase à educação. Apontamos como possíveis caminhos aprofundar estudos e práticas a partir do legado Freireano, reinventando-o em um processo contínuo de ação-reflexão-ação em busca do sonho na construção da resistência. 


\section{Trajetória de Paulo Freire na construção do inédito viável}

Em 1963, além das manchetes que retratavam a problemática do cotidiano nordestino desafiado pelo trinômio: fome - seca - pobreza, no pacato município de Angicos, cidadezinha da região central do sertão do Rio Grande do Norte, foram alfabetizados 300 trabalhadores rurais, em 45 dias, por 15 jovens universitários. O feito ganhou os noticiários e, em virtude do sucesso do método de alfabetização de adultos, que em 40 horas apresentava resultados positivos, em pouco tempo, a pacata Angicos passou a ser ponto de convergência da mídia, com a chegada de repórteres de destacados jornais, tanto brasileiros, como estrangeiros, conforme comenta Germano (1997) "com a vinda de representantes do New York Times, do Time Magazine, do Herald Tribune, do Sunday Times, do United e da Associated Press, do Le Monde” (p. 389), como também de especialistas em educação, pois alfabetização, foi e continua sendo um grande desafio, tanto para alfabetizandos, especialistas e gestores públicos.

Os alfabetizandos se reuniam nos Círculos de Cultura, cujo objetivo central não era apenas dominar a lecto-escrita, mas também de assumir seu protagonismo na sua história, na sua cultura, ampliando o olhar sobre a realidade, pois Freire (1967) estava convencido, concordando com Mannheim (1942), de que a ampliação dos processos de democratização resulta em rompimento com o estado de ignorância das massas.

Ignorância, não apenas pela situação de analfabetismo, mas também pela

inexperiência de participação e ingerência delas, a serem substituídas pela participação crítica, uma forma de sabedoria. Participação em termos críticos, somente como poderia ser possível a sua transformação em povo, capaz de optar e decidir (FREIRE, 1967, p. 102).

Freire participava do Movimento de Cultura Popular do Recife, coordenando o "Projeto de Educação de Adultos", constituído pelo "Círculo de Cultura" e o "Centro de Cultura". Foi um momento ímpar, em que tinha a possibilidade de confrontar suas teorias com a concretude das experiências ocorridas nos Círculos de Cultura,

A proposta de alfabetização Freiriana com caráter essencialmente dialógico, partia do universo vocabular dos alfabetizandos, que se encontravam ali conscientes de estarem desvelando a realidade e gradativamente emancipando-se da visão "ingênua" inicial, para conquistarem a liberdade, sem medo, sem ressentimentos, sem causar perigo. Para muitos estudantes uma educação libertadora provocava insegurança e medo, assim como pensavam que conscientização ou consciência crítica poderia trazer perigos. Ao discutir sobre a periculosidade da aquisição da consciência crítica, Freire (1983) registra o relato de um alfabetizando: 
Talvez seja eu, entre os senhores, o único de origem operária. Não posso dizer que haja entendido todas as palavras que foram ditas aqui, mas uma coisa posso afirmar: cheguei a esse curso ingênuo e, ao descobrir-me ingênuo, comecei a tornar-me crítico. Esta descoberta, contudo, nem me faz fanático, nem me dá a sensação de desmoronamento (p. 23).

O debate dizia respeito aos prováveis perigos da conscientização, se a pessoa que passou pelo processo de conscientizar-se, correria ou não o risco de cair num "fanatismo destrutivo" ou na "sensação de desmoronamento moral do mundo", explicita Freire (1983, p. 23-24). O depoimento acima é elucidativo. Contudo Freire vai além, esclarecendo que o que ocorre é justamente o contrário, é a conscientização que evita cair no fanatismo, levando o sujeito à inserção "no seu processo histórico", isto é, possibilitando que assuma seu protagonismo histórico. Por outro lado, entende que o sentimento de medo da liberdade revelaria a negação da percepção da injustiça: "Melhor será que a situação concreta de injustiça não se constitua num 'percebido' claro para a consciência dos que a sofrem” (FREIRE, 1983, p.24).

A participação dos inscritos nos Círculos de Cultura e os consideráveis avanços no processo da leitura e escrita foram avaliados como experiências revolucionárias, fosse em Angicos ou em Natal, como atesta a manchete em um jornal, da época: "Povo aprende a ler debatendo problemas"1. Freire transpirava entusiasmo, o que se percebe em entrevista concedida ao periódico Última Hora (1963)

Acabo de regressar de Angicos, onde estive por uma semana em companhia da professora Aurenice Cardoso e do senhor Paulo Pacheco diretor do SEC ${ }^{2}$. O que vimos ali é quase indescritível. Com apenas nove (9) aulas, mais de 70\% dos alunos criavam palavras, começavam a ler e a construir frases inteiras. Mais ainda - debatiam os problemas locais e nacionais. (FREIRE, 1963, p. 02)

Muito jovem ainda, Freire envolveu-se com a alfabetização de adultos, e as funções a que passou a ocupar tangenciavam esta temática, conforme narra Beisiegel (2010), tanto é que em maio de 1960, assumiu a direção da Divisão de Pesquisas do Movimento de Cultura Popular (MCP), movimento criado pelo prefeito de Recife, Miguel Arraes. Em fevereiro do ano de 1962, passou a dirigir o Serviço de Extensão Cultural (SEC) da Universidade do Recife, e na metade do ano seguinte, foi indicado para presidir a Comissão Nacional de Cultura Popular, recémcriada pelo Ministro da Educação Paulo de Tarso. Em março do ano seguinte, assumiu a coordenação do Programa Nacional de Alfabetização, sob auspício do Ministério da Educação, empregando o método Paulo Freire para alfabetização de adultos.

\footnotetext{
${ }^{1}$ Fonte: http://acervo.paulofreire.org/xmlui/handle/7891/3016” \1 "page/1/mode/1up

${ }^{2}$ SEC designava o Serviço de Extensão Cultural da Universidade de Recife denominada Universidade Federal de Pernambuco, a partir de 1965.
} 
Freire já era experiente e acumulava mais de 15 anos atuando na educação de adultos, envolvendo populações rurais e urbanas, proletárias (trabalhadores de fábricas ou pequenas indústrias) e subproletárias (massa de trabalhadores não qualificados, que vivem de biscates, sem qualquer estabilidade financeira). Contudo os déficits em educação eram alarmantes, refletindo o fracasso na alfabetização ou a inadequação da proposta educacional. Em números, "havia 4.000.000 de crianças em idade escolar sem escola, e 16.000.000 de analfabetos com idade a partir de 14 anos" (FREIRE, 1967, 101). O mote de Freire era a democratização da cultura. Para tanto este quadro de fracasso necessitava ser revertido, pois era empecilho para a construção de uma mentalidade democrática, para o alcance do progresso e para a emancipação material e intelectual. Destaca-se que o sucesso da proposta de alfabetização de adultos, capaz de reverter o quadro em que se encontrava a educação brasileira, entusiasmou políticos, a sociedade e gestores públicos. O então presidente da República, João Goulart, deslocou-se para Angicos, acompanhado do governador do Rio Grande do Norte, Aluízio Alves, para prestigiar o encerramento das atividades dos Círculos de Cultura, no longínquo dia 02 de abril de 1963, conforme registra Germano (1997).

Foi um tempo de intensas mobilizações e reivindicações em torno das reformas de base, propostas pelo governo Goulart que abrangiam o campo educacional, fiscal, político e agrário. Os Sindicatos Rurais e as Ligas Camponesas fortalecidos levantavam a bandeira da reforma agrária, partidos e políticos mais à esquerda, alcançavam visibilidade, ao mesmo tempo, começavam a projetar-se as Comunidades Eclesiais de Base - CEB's, ligadas à Igreja Católica tratando questões sociais. Conforme Betto (1981) as Comunidades Eclesiais de Base foram

\footnotetext{
um desafio lançado a Igreja, pela esperança de libertação dos povos latinoamericanos. Através de suas comunidades de bases, de seus agentes de pastorais descobrir a maneira mais evangélica de tornar essa esperança uma prática eficaz de transformação da história e busca do mundo de justiça e amor. (1981, p. 1).
}

As CEB's no Brasil nasceram no seio da Igreja Católica, no início dos anos 60, num contexto de rica fermentação dos movimentos, em que destacamos os grupos ligados à Ação Católica: Juventude Universitária Católica (JUC), a Juventude Estudantil Católica (JEC), a Juventude Operária Católica (JOC) e o Movimento de Educação de Base (MEB), fundado em março de 1961 e vinculado à Conferência Nacional dos Bispos do Brasil (CNBB). Na atualidade, o MEB atua nas regiões Norte e Nordeste, no Distrito Federal e no norte do estado de Minas Gerais, regiões com maiores índices de exclusão social, sempre referenciado nos princípios filosóficos de Paulo Freire, que norteiam a educação popular. O MEB tem por missão 
"contribuir para promoção humana integral e superação da desigualdade social por meio de programas de educação popular libertadora ao longo da vida"”.

No contexto internacional, a América Latina encontrava-se envolta nas tensões da Guerra Fria, em que dois modelos políticos antagônicos estavam em disputa: o capitalismo, representado pelos Estados Unidos da América (USA) e o socialismo, representado pela União Soviética (URSS). Nos Estados Unidos, potencializados, em especial pela propaganda e pelo macarthismo, ${ }^{4}$ construiu-se no imaginário social a figura do monstro do comunismo, referenciada na Revolução Cubana, ocorrida em 1959, com objetivo de afastar do poder o ditador Fulgêncio Batista. Conforme Silva (2019), as medidas nacionalistas tomadas por Fidel Castro, como reforma agrária, que resultou no fim de grandes latifúndios e nacionalização de empresas estrangeiras, desagradaram interesses norte-americanos, resultando na tentativa de invasão da Baía dos Porcos, em abril de 1961. Apesar de a invasão ter sido barrada pelos insulanos, Castro reagiu, anunciando o alinhamento ao regime socialista soviético, o que provocou sanções, isolamento comercial e um embargo econômico contra Cuba, que se estende por mais de 50 anos.

O Brasil encontrava-se mergulhado neste cenário de tensão, em virtude de medidas tomadas pelo governo, que desagradaram às classes dominantes, desde início dos anos 50, com o governo Vargas. O aumento em 100\% do salário-mínimo conferido aos trabalhadores, em 1954, pelo Ministro do Trabalho, João Goulart desagradou militares e setores produtivos, que logo associaram tais medidas ao comunismo. Em 1955, ano seguinte à morte de Vargas, João Goulart assumiu a Vice-Presidência da República, ao lado de Juscelino Kubitschek, período em que se estreitaram os vínculos entre o Vice-Presidente e o movimento sindical. Em 1961, Jânio Quadros foi eleito presidente, um político conservador que, ao mesmo tempo em que se alinhava às exigências do Fundo Monetário Internacional - FMI, acenava para estabelecimento de relações diplomáticas com países do eixo socialista, governando portanto de forma dúbia e contrariando grupos poderosos brasileiros. Acabou renunciando, oportunidade em que assumiu o governo, o vice-presidente João Goulart. Jango, como era chamado, uma excelente oportunidade para ampliação de apoio aos excluídos, o que já vinha realizando, desde o tempo em que fora ministro, do governo Vargas.

\footnotetext{
${ }^{3}$ Conforme informações retiradas da página do Movimento, na Internet: http://www.meb.org.br/quem-somos

${ }^{4}$ Macarthismo foi um movimento criado pelo senador Joseph Raymond McCarthy com objetivo de denunciar e perseguir comunistas, para tanto, foram criados comitês e promulgadas leis, que impunham sanções e penalidades contra quem se envolvesse em atividades com viés comunista, consideradas antiamericanas, portanto de inimigos da nação, conforme destaca o Site: https://brasilescola.uol.com.br/historia-daamerica/macartismo.html
} 
Investir em alfabetização de adultos era condição para o desenvolvimento do país, e no início de 1964, com a criação do Plano Nacional de Alfabetização, a filosofia e o método de alfabetização de Paulo Freire foram adotados pelo governo federal. A educação era vista como instrumento revolucionário, capaz de politizar e conscientizar o povo, possibilitando sua efetiva e consciente participação (política), e "influenciar decisivamente na transformação da sociedade brasileira" (GERMANO, 1997, p. 390).

Tais transformações para Freire (1967) deveriam atingir o campo técnico, políticoeconômico, e até mesmo reformas estruturais, seguidas de mudanças para nova mentalidade. A questão, destaca Freire (1967, p. 87),

\begin{abstract}
estaria em que a emersão do povo e suas crescentes reivindicações, ampliando-se cada vez mais, não assustassem tanto à classe dos mais poderosos, para quem, repita-se Lipset, "os direitos políticos das classes mais baixas, particularmente o de interferir no poder (lhes parece) como essencialmente absurdo e imoral.
\end{abstract}

Para Freire, era de se esperar que as reivindicações das classes populares, construídas com criticidade e autonomia intelectual, não assustassem a classe dos mais poderosos, isto é, a elite nacional. Contudo, reconhece-se que a alfabetização que aconteceu nos encontros dos Círculos de Cultura não era neutra, pois educação é um ato político (FREIRE, 1989) e a aquisição da leitura e escrita, não deixa de ser um momento de empoderamento, pois no decorrer do processo, o educando desenvolveu criticidade e passou a reivindicar o direito à participação e o direito de votar e ser votado.

O autor reafirma que "sempre viu a alfabetização de adultos como um ato político, portanto um ato de conhecimento, um ato criador" Freire (1989, p. 13). A memorização mecânica de sílabas ou palavras, sem qualquer significado para o educando, cedeu lugar ao processo criador do educando, palavra lida ou escrita pertencente ao universo do alfabetizando, carregada de significações e/ou emoções, num permanente movimento: "do mundo à palavra e da palavra ao mundo"; a palavra dita carrega as significações e compreensões que temos do mundo. E o mestre vai além, propondo "que a leitura da palavra não é apenas precedida pela leitura do mundo, mas por certa forma de "escrevê-lo" ou de "reescrevê-lo"" (FREIRE, 1989, p. 13), destacando que é o alfabetizando que indicará os temas e palavras geradoras do processo de alfabetização. O universo vocabular do educando deverá estar inundado de palavras significativas para ele, e "expressando a sua real linguagem, os seus anseios, as suas inquietações, as suas reivindicações, os seus sonhos" (FREIRE, 1989, p.13). 
Na medida em que se consolidava o êxito da alfabetização que ocorria nos Círculos de Cultura, com as equipes envolvidas, entusiasmadas com a possibilidade de reversão dos baixos índices da lecto-escrita e os educandos participando, relatou Freire (1963, p. 1):

Assistimos durante os debates de aula, o grupo de alunos rejeitar uma "posição de massa" e reinventar a atitude decisória de povo. Surpreendemos em todos os círculos a consciência bem nítida de que a arregimentação e organização do povo é o caminho que levará à solução dos grandes problemas nacionais. Por isso "falam já em unir-se, em associar-se na defesa de seus direitos raramente reconhecidos, e quase nunca respeitados".

Alfabetizados, os educandos sonhavam com novos voos, alguns, inclusive pensaram candidatarem-se, o que segundo Freire $(1967$, p. 87) seria mais "em termos muitas vezes emocionais". A efetivação das reformas de base previstas pelo governo, a possibilidade de melhores empregos com consequente melhoria salarial, e a probabilidade de inserção na política partidária, com conquista de espaços de poder, por trabalhadores, até a pouco tempo excluídos socialmente, provocou a reação da elite nacional frente às mudanças que estavam sendo delineado, o que deveria ter sido previsto, não fosse à atitude ingênua dos atores sociais.

Ao lado de dezenas de iniciativas que buscavam oportunizar ao educando adulto o domínio da leitura e escrita, o desenvolvimento da criticidade, a garantia de sua cidadania, era indicada a necessidade de "reforma urgente e total" e de uma "educação para a responsabilidade social e política" (FREIRE, 1967, p. 88). Contudo, a reação das elites a estes avanços contrariou as expectativas.

[...] a reação das classes dominantes, e dos seus aliados norte-americanos, de amplos setores das classes médias e das Forças Armadas redundou na deposição de Jango e na implantação de um regime político de cunho ditatorial cuja principal preocupação era estancar, conter, as mobilizações sociais. É claro que a repressão atingiu duramente o campo educacional, a educação popular. Entre os atingidos encontravase, evidentemente, Paulo Freire: preso, processado, exilado, considerado subversivo (GERMANO, 1997, p. 391).

Em defesa da manutenção de seus privilégios e interesses de grupo, a elite se posicionaria contra a cruzada empreendida por Freire, pois um povo semialfabetizado e despreparado intelectualmente seria mais facilmente manipulável. Por outro lado, a emersão popular era vista como ameaça, como reconheceu Freire (1967, p. 88):

A classe média, sempre em busca de ascensão e privilégios, temendo naturalmente sua proletarização, ingênua e emocionalizada, via na emersão popular, no mínimo, uma ameaça ao que lhe parecia sua paz. Daí a sua posição reacionária diante da emersão popular.

E assim, de educador destacado no campo da alfabetização de adultos e educação popular, Freire passou a ser perseguido, associado ao comunismo, por propor a substituição de uma alfabetização mecânica, como no clássico exemplo: "Ivo viu a uva", para um trabalho de 
leitura crítica, de conscientização dos educandos, defendendo a participação política do povo. Ao desvelarem os códigos da leitura e escrita, os educandos revelavam-se pessoas críticas, capazes de escolhas e de posturas, isto é, posturas políticas, sabendo muito bem "a favor de quem e contra quem eu aprendo".

Após o Golpe Militar, em março de 1964, Freire passou 72 dias preso e partiu como exilado político para o Chile, onde deu continuidade a suas pesquisas, estudos e experimentações, publicando em 1968, no exílio, a obra Pedagogia do Oprimido. Em 1970, Pedagogia do Oprimido foi publicada nos Estados Unidos e quatro anos, depois, foi lançado no Brasil em 1974.

O período que se instalou logo após o Golpe de 1964, com a destituição do presidente de João Goulart e a chegada dos militares ao poder foi um período de violenta repressão, de prisões irregulares, de tortura e assassinatos que atingiu em especial os setores articulados à esquerda, como o Comando Geral dos Trabalhadores (CGT), a União Nacional dos Estudantes (UNE), as Ligas Camponesas e grupos católicos como a Juventude Universitária Católica (JUC) e a Ação Popular (AP). Foram 21 anos de ditadura militar (1964-1985), de banimentos e desaparecimentos, de paus de arara, de sessões de tortura nos porões do Destacamento de Operações de Informação (DOI) - Centro de Operações de Defesa Interna (CODI), tempo que a história registrou, mas não condenou pela Lei de Anistia (Lei n 6.683, de 28/08/1979) que perdoou quem sofreu e quem praticou ações da ditadura. O Brasil não se reencontrou com seus erros do passado. As consequências foram percebidas nos episódios pró-golpe de 2016, quando vários grupos vestindo camisetas amarelas, saiu às ruas reivindicando a volta dos militares, apoiando o Golpe parlamentar, jurídico e midiático sofrido pela presidenta Dilma Rousseff. Na conjuntura internacional e no Brasil destaca-se a onda neoconservadora.

\section{A onda neoconservadora na contemporaneidade}

Esta guinada à direita é um fenômeno observado mundialmente. Nos últimos anos, temos a saída do Reino Unido da União Europeia (UE), o Brexit e o crescimento de partidos políticos ultradireitistas. Brexit é um termo inglês formado pela aglutinação da palavra inglesa British, que significa britânico e Exit, que quer dizer saída. Significa que o Reino Unido está deixando o bloco político e econômico da UE, devido a um acordo político inicial, pelo então candidato a Primeiro Ministro David Cameron, com o Partido da Independência do Reino Unido (UKIP). O UKIP é um partido nacionalista, que em troca do apoio a Cameron, exigiu a convocação de um plebiscito, para que os eleitores opinassem sobre permanecer ou não na UE. 
Dentre os pontos de descontentamento do UKIP com a UE estavam assuntos econômicos e de imigração. Após quase 60 anos de participação na UE, com a justificativa de defender a soberania nacional; controle de fronteiras; por orgulho da identidade britânica e em virtude do crescimento do UKIP, dentre outros pontos, O Reino Unido passa pelo Brexit.

Ao buscar compreender os motivos que levaram britânicos a decidirem abandonar um acordo de integração com 28 países membros da UE, o qual tinha por objetivo inicial evitar o surgimento de rivalidades, como aquelas que desembocaram, no passado, nas duas grandes guerras mundiais, analistas apontam como causa o recrudescimento do conservadorismo. Ressaltamos que a saída do Reino Unido da UE reacendeu movimentos separatistas, como o debate pela independência da Escócia e reunificação da Irlanda do Norte, uma vez que a população desses países votou pela permanência na UE.

O cenário atual apresenta-se conturbado: é o Brexit no Reino Unido; a eleição de Donald Trump, em 2016; na França, a acirrada disputa entre o candidato social liberal Emmanuel Macron e a ultradireitista Marine Le Pen. Na Alemanha, as eleições ocorreram em setembro de 2017, com votação para os membros do Bundestang, isto é, os Deputados Federais, que escolhem o Chanceler. Para formar o novo governo, o Chanceler precisa receber o apoio da maioria absoluta dos membros do Bundestang. A disputa foi vencida, mais uma vez, pela Chanceler Angela Merkel, representante do partido de centro-direita, União Democrata Cristã (CDU), cargo que ocupa desde 2005. Por outro lado, pela primeira vez foram eleitos representantes do Partido Alternativa para a Alemanha (AFD), um partido nacionalista, de extrema direita, criado há apenas quatro anos.

Na Áustria, as eleições legislativas ocorridas em 15 de outubro de 2017 deram a vitória ao conservador Partido Popular $(O ̈ V P)$, seguido do Partido Social Democrata (SPO) e do ultranacionalista Partido da Liberdade (FPÖ). Entre o programa de governo para os próximos cinco anos destaca-se a permanência da Áustria na União Europeia, o fortalecimento da polícia, a diminuição dos impostos e o aumento das rejeições aos refugiados e estrangeiros.

Na República Tcheca, as eleições foram decididas, em outubro de 2017, após o segundo turno, com a reeleição do social democrata Milos Zeman, autodenominado "eurofederalista". Milos Zeman derrotou Jiri Drahosex presidente da União Europeia (UE). Especialistas atribuem a vitória do social democrata, em virtude de sua postura contrária a algumas políticas pautadas pela União Europeia, no tocante à imigração, além de manter boas relações com países como Rússia e China, pertencentes ao antigo bloco do Leste Europeu.

Na Itália, as eleições de 2018, deram a vitória a partidos nacionalistas e anti-imigração; no Brasil, em 2018, foi a vez de Jair Bolsonaro ser eleito, culminando, naquele mesmo ano, 
com a escolha de uma maioria de direita nacionalista para o Parlamento Europeu. Sinaliza-se para o estabelecimento de uma nova onda conservadora, que atinge não apenas o campo político, mas também o social, cultural e econômico.

No Brasil, o retrocesso representado pela reforma da previdência, com perda de direitos dos trabalhadores, a proposta de implantação de projeto contra a "doutrinação" nas escolas, denominado "Escola sem Partido", sob acusação de que Universidades e professores são campos de predominância de comunistas, a tentativa de silenciamento de artistas e pensadores, como a censura imposta à Exposição Queer Museu, no Santander Cultural; as agressões contra a presença da filósofa Judith Butler, em seminário realizado no Serviço Social do Comércio Pompeia (SESC), em São Paulo, considerada pelos agressores, como "uma representante da ideologia de gênero" e o combate a esta ideologia nas escolas brasileiras, são exemplos reais do conservadorismo que grassa no país.

Por conservadorismo entendemos como Bobbio, Matteucci e Pasquino (1998, p. 242) as "ideias e atitudes que visam à manutenção do sistema político existente e dos seus modos de funcionamento, apresentando-se como contraponto das forças inovadoras". Conservadorismo é uma palavra empregada mais como adjetivo, para qualificar práticas, ideias ou atitudes, mas poderá também ser usada como substantivo, de difícil conceituação, segundo os autores.

Para Apple (2004, p. 114), “os neoliberais são o elemento mais poderoso dentro da restauração conservadora. São orientados pela perspectiva do Estado fraco. Assim, o que é privado é necessariamente bom e o que é público é necessariamente ruim". A politica econômica neoliberal hoje no Brasil a partir do Golpe com o impeachment de Dilma Rousseff e com isso, Michel Temer assumir a Presidência do Brasil ocorre uma guinada neoliberal e com as eleições de 2018 está mais presente que nunca essa pauta para o Brasil. A ideia é vender tudo que for possível, diminuir consideravelmente a presença do Estado. Tornando a educação uma mercadoria, de acordo com Apple (2004, p. 115 - 116)

\footnotetext{
as escolas são feitas para professores e burocratas do Estado e não para "consumidores"[...]. Para os neoliberais, o mundo em essência é um vasto supermercado. A escolha do "consumidor" é o que garante a democracia. [...] em vez de democracia ser um conceito político, ela é transformada num conceito inteiramente econômico.
}

O cenário pelo qual passa atualmente a sociedade global, com permanente tensão e ameaças de violações de direitos é chamado de neoconservadorismo. Para cientistas políticos, como Mounk (2019) esta guinada à direita foi provocada pelas instabilidades sofridas pelas classes médias, em virtude da falta de atendimento a suas necessidades, pela perda de poder aquisitivo e medo de uma possível degradação. 
No neoconservadorismo de acordo com Apple (2004) ao contrário dos neoliberais, os neoconservadores optam pela concepção de Estado forte, em especial ao regulamentar as questões referentes ao conhecimento, valores e corpo. Dentre as políticas propostas, Apple (2004) destaca "o currículo nacional, o exame nacional, um "retorno" a altos padrões de qualidade, uma revivificação da "tradição ocidental" e o patriotismo" (2004, p. 106).

Observa-se claramente no Brasil de hoje estas características apontadas por Apple no momento que estamos vivenciando um retrocesso histórico como país nunca visto anteriormente, porém com um estado fraco A atualidade do artigo de Apple publicado em 1998 nos Estados Unidos, em uma reflexão sobre o que ocorria naquele momento na educação e os novos blocos hegemônicos apontava como um "excesso de democracia" - cultural e política"[...] era visto de acordo com o autor como uma das maiores causas do "declínio econômico e cultural” (Apple, 2004, p. 112). Dependendo de quem está com o poder temos idas e vindas de retrocessos.

Frente à situação que vivemos como construir espaços de resistência na práxis em busca do 'inédito-viável'?

\section{A Práxis necessária para enfrentar os desafios de uma realidade opressora}

Frente ao cenário que se descortina, e ainda sob efeito das celebrações dos 50 anos de lançamento da Pedagogia do Oprimido, nos perguntamos como o legado de Freire poderá contribuir para arrefecer o panorama atual? Em entrevista, cujo título foi "Pedagogia do Oprimido 30 anos depois", realizada em 1993, em excerto na obra Pedagogia dos Sonhos Possíveis, Parte III, Freire falava sobre a atualidade da Pedagogia do Oprimido, 30 anos depois da sua publicação. E agora, ao completar 50 anos, continuamos afirmando sua atualidade. Quando ocorreu essa entrevista, o autor mencionava que estávamos no final do século, e também do milênio. Freire sempre valorizou o papel histórico da consciência, enfatizando "a natureza inalienável da individualidade dos sujeitos”. (FREIRE, 2001, p. 210). Explanava sobre o predomínio das teses liberais, que descartaram questões sociais, do discurso político, ao qual Freire chamou de "pós-modernamente reacionário", que facilmente envolveu intelectuais até então tidos como progressistas. Lamentava que um pequeno grupo deixou de construir a luta socialista para reavivar o stalinismo.

Freire acalentava o sonho socialista, uma vez que as condições materiais da existência que plasmaram tal sonho continuam atuais e o capitalismo não conseguiu resolver a problemática da "miséria, da injustiça e da opressão" (FREIRE, 2001, p. 209). Ao mesmo 
tempo conclamava para reconstruirmos a luta pelo socialismo, sempre pela via democrática, superando o pragmatismo autoritário com que a esquerda concebia a História, como determinismo e não como possibilidade. Assim declarou:

\begin{abstract}
para que vivamos a História como possibilidade, compreendendo que o futuro não é inexorável, que o futuro é problemático, e deve ser construído porque não está prédado. Na medida em que se entende a História como possibilidade, como futuro que se problematiza, necessariamente superamos o dogmatismo mecanicista - de origem marxista, mas não de responsabilidade apenas de Marx - e passamos a compreender o importantíssimo papel histórico da consciência, o papel da subjetividade na feitura da História (FREIRE, 2001, p. 210).
\end{abstract}

Para o autor viver a História como possibilidade e não como dada permite que construamos o futuro, um futuro que se pensa, se questiona, se planeja, superando o "dogmatismo mecanicista" de origem marxista e passaremos assim a "compreender o papel histórico da consciência, o papel da subjetividade na feitura da História” (FREIRE, 2001, p. 210), categoria sempre valorizada por Freire. Ao afirmar que precisamos viver a História como possibilidade, Freire sinaliza para o protagonismo do povo e busca pela concretização dos nossos sonhos, através da superação das condições históricas que exclui econômica, culturalmente e socialmente a maioria da população. Freire desenvolveu um pensamento pedagógico assumidamente político, segundo ele, o objetivo maior da educação é conscientizar o educando, a educanda. Isso significa, em relação às parcelas desfavorecidas da sociedade, levá-las a entender sua situação de oprimidas e agir em favor da própria libertação.

Tal processo de conscientização, em um primeiro momento, passa pela tomada de consciência, com uma postura ainda ingênua, para atingir depois, a esfera crítica "na qual a realidade se dá como objeto cognoscível, e na qual o homem assume uma posição epistemológica" (FREIRE, 1980, p. 26). Destacando que o homem é o sujeito cognoscente, isto é aquele que tem a capacidade de conhecer, enquanto o objeto cognoscível é o objeto passível de ser conhecido, pode ser qualquer objeto. Em Freire, o objeto a ser conhecido, "des-velado", é a realidade (fatos, fenômenos). Ao desvelar a realidade, o homem assume uma posição epistemológica, isto é, conhece a realidade, analisa e é capaz de se posicionar criticamente sobre ela. Conforme Freire (1980) “a conscientização é, neste sentido, um teste de realidade" e complementa:

\footnotetext{
Quanto mais conscientização, mais se "desvela" a realidade, mais se penetra na essência fenomênica do objeto, frente ao qual nos encontramos para analisá-lo. Por esta mesma razão, a conscientização não consiste em "estar frente à realidade" assumindo uma posição falsamente intelectual. A conscientização não pode existir fora da "práxis", ou melhor, sem o ato ação-reflexão. Esta unidade dialética constitui, de maneira permanente, o modo de ser ou de transformar o mundo que caracteriza os homens (1980, p. 26).
} 
Conscientizados, os homens tornam-se sujeitos de ação, em permanente atuação, fazendo e refazendo o mundo. Por outro lado, Freire (2001, p. 211) ressalta a importância da "leitura do mundo e do texto", pois ao compreender "a favor de quem e a favor de que o sistema" se organiza, o indivíduo poderá inferir quais armas precisará dispor para se manter resistindo.

Ao escrevermos este artigo, o Brasil passa por um momento sui generis de "aparente" imobilismo e uma série de questões são levantadas: De certa forma estamos impactados com toda esta enxurrada de perdas de direitos. Seria uma "anestesia-histórica", como tão bem conceituou Freire? Sofremos muitas perdas, como a Reforma da Previdência, que hoje se encontra no Senado para apreciação, a Reforma Trabalhista, a classe trabalhadora perde direitos trabalhistas historicamente conquistados, o Programa Future-se, apresentado pelo Ministério de Educação, no mês de julho de 2018, atinge a autonomia das Universidades e dos Institutos Federais de Educação, com um caráter privatista, além de inúmeras privatizações de empresas estatais sendo gestadas.

Completando toda essa situação de ataque aos Direitos, ocorrem as queimadas criminosas na Amazônia, matando uma floresta que é considerada o pulmão do mundo, animais queimados vivos, todo um bioma sendo destruído e povos originários da floresta sendo dizimados por ganância do capital. Frente a esse panorama, não estaremos em uma "situaçãolimite" (FREIRE, 1993, p.138), que nos impede divisar o "inédito viável”? Ao mergulharmos no "cansaço existencial" e na "anestesia-histórica", corremos o risco de não perceber as possibilidades do "inédito viável” que estão logo à frente. Para Freire (1983, p. 106),

\begin{abstract}
as situações-limites [...] revelam-se como dimensões concretas e históricas de uma dada realidade, mas não são as "situações limites", em si mesmas, geradoras de um clima de desesperança, mas a percepção que os homens tenham delas num dado momento histórico.
\end{abstract}

A superação de situações limites de acordo com Freire (1983), não existe fora das relações homem-mundo e ocorre a partir da ação dos homens sobre a realidade concreta onde acontecem as mesmas. As situações-limites seriam as barreiras que encontramos, Freire diz que

o próprio dos homens é estar, como consciência de si e do mundo, em relação ao enfrentamento com sua realidade em que, historicamente se dão as "situaçõeslimites". E este enfrentamento com a realidade para a superação dos obstáculos só pode ser feito historicamente, como historicamente se objetivam as "situaçõeslimites". (FREIRE, 1983, p. 107).

Então como estamos enfrentando as situações limites em que nos encontramos? Quais foram às ações concretas que realizamos nos últimos tempos? Mobilizações eventuais com várias pautas e com pouca discussão. Realizando as ações e não refletindo sobre as mesmas, 
qual consciência está contribuindo para formar se não tiramos aprendizados dos momentos vividos? Precisamos fundamentar nossas ações e entender porque as estamos realizando, com que fim. Vemos ações esparsas e soltas de um objetivo a perseguir em longo prazo.

Qual “inédito-viável” perseguir?

É impossível estar no mundo apoliticamente, neutramente. Não dá para estar. Há sempre valoração, há sempre comparação, há sempre escolha que demanda decisão, ruptura, e isso tudo tem que ver com a forma de estar sendo no mundo [...]. A História tem uma horizontalidade, que não significa repetição, nem perpetuação, mas continuidade. (FREIRE, 2001, p. 213).

Quais escolhas? Quais rupturas? Quais decisões? Considerando conforme o autor que a História é continuidade. Acreditamos que precisamos construir mutirões de estudos e ações práticas e reflexivas com diferentes grupos sociais, sair da "bolha" que nos encontramos, não nos vemos e não nos escutamos, falando sempre com as mesmas pessoas que normalmente pensam como nós. Não queremos de forma alguma ser prescritivo, ou dar receita, mas construir conjuntamente um caminho de possibilidades, tendo presente às perguntas epistemológicas de Freire: Como? Para quem? Por quê? Contra quem? E a favor de quem?

Uma questão recorrente, após a análise da conjuntura atual brasileira, em eventos dos quais participamos diz respeito a perguntas sobre qual caminho seguir para trabalharmos o processo de rompimento ou enfrentamento da "situação-limite" em que nos encontramos. Temos refletido sobre as possibilidades a seguir e ao como fazer. Entendemos de que os caminhos são vários, precisamos começar e nossa aposta está no processo de conscientização, nele encontramos quem sabe um reinício:

Quanto mais os oprimidos vejam os opressores como imbatíveis, portadores de um poder insuperável, tanto menos acreditam em si mesmos. Uma das tarefas da educação popular progressista ontem como hoje, é procurar por meio da compreensão crítica de como se dão os conflitos sociais, ajudar o processo no qual a fraqueza dos oprimidos se vai tornando força capaz de transformar a força dos opressores em fraqueza. Esta é uma esperança que nos move. (FREIRE, 1993, p.126).

A introjeção desse sentimento de inferioridade pelo oprimido será superada através da conscientização e de uma educação libertadora que ao se propor crítica, rompe com a naturalização das desigualdades socioeconômicas, e ao se propor dialógica, rompe com a concepção bancária e a domesticação da educação.

O que se pede hoje, é mudar o olhar do oprimido, esperançar-se com a ideia de recriar o mundo, e assim, construindo a resistência. Como? Aprofundando a compreensão sobre nossa prática para melhorar a prática seguinte, em diálogo com autores e atores que a embasam. $\mathrm{O}$ momento é de haurir forças, para desenharmos a resistência. Aprendemos com Paulo Freire 
conhecido como "cavalheiro da esperança" e também "andarilho da utopia", como bem lembra Cortella (2018, p. 27)

Freire não desanimava "não perdia a alma" ele conhecia bem a possibilidade das pessoas desanimarem, [...] saiu mundo afora animando, $[. .$.$] impedindo que as pessoas$ achassem que as coisas não têm alternativas, [...] e de dizer que a gente não poderia desistir.

Nessa perspectiva estamos estudando e acompanhando há algum tempo as metodologias participativas com Vilassante (2006, 2011, 2015), embasadas em Paulo Freire, Fals Borda, Carlos Brandão, entre outros, cujo objetivo é promover transformações sociais. As mesmas servem para conhecer melhor os problemas sociais dos locais de atuação, compartilhando com a população e construindo caminhos de superação. As pessoas passam a serem através desse processo, sujeitos ativos e protagonistas de um projeto de transformação de seu entorno e realidade imediata, sempre a partir de uma base social e de problemas cotidianos. As metodologias são utilizadas para construir, em conjunto, um plano de ação a partir de problemas e da necessidade de equacioná-los. Tal ação incide sobre a estrutura social, para transformá-la em co-laboração, união e organização e estas não ocorrem fora da práxis, que para Freire (1983, p. 108) "práxis que sendo reflexão e ação verdadeiramente transformadora da realidade, é fonte de conhecimento reflexivo e criação".

Com isso, "na teoria dialógica da ação os sujeitos se encontram para a transformação do mundo em co-laboração,[...] numa perspectiva de sujeitos que se encontram para a pronúncia do mundo, para sua transformação" (FREIRE,1983, p. 196). Aqui não é a ideia de alguém que comande as pessoas, mas estas pessoas em comunicação, pressuposto da ação dialógica, se constituem enquanto sujeitos que aderem e engaja pela libertação em comunhão para a ação. E para que isso ocorra os sujeitos precisam estar unidos, organizados e em relação.

$\mathrm{Na}$ educação, o mergulho em determinadas comunidades de experiência requer que educadores respeitem os conhecimentos do grupo, reconhecendo o que sabem e o que desejam saber. Freire (1993, p. 67) alertava que "ninguém ensina o que não sabe, mas também, ninguém [...] deveria ensinar o que sabe sem, [...] saber o que já sabem e em que, nível sabe aqueles e aquelas a quem vai ensinar". Tal arcabouço de conhecimento constitui o que Freire $(1989$, p. 9) chamou de "leitura de mundo", isto é, a compreensão da sua realidade, do seu contexto, podendo relacionar de forma dinâmica linguagem e realidade.

Isto posto fica o desafio para irmos à luta e construir a busca pelo "inédito-viável”, em uma proposta de construção de uma democracia participativa, de uma sociedade com justiça 
social a partir do direito de desvelar nossa visão de mundo. Vamos assim construindo a resistência num esperançar-se.

\section{Considerações}

Nestes últimos dias, em que nos envolvemos na feitura deste artigo, com o objetivo de refletir sobre o legado de Paulo Freire e os processos possíveis de resistência a partir da educação popular no enfrentamento à onda neoconservadora que vivemos atualmente, passamos por uma espécie de "acolhimento" à escrita do mestre. Mergulhamos nas profundezas dos seus escritos e voltamos de lá com corações e mentes repletos de amorosidade, as nuvens cinza da decepção e medo que pairavam sobre nós foram dissipadas, graças às lições do "andarilho da utopia", de prosseguir com doçura. A mensagem final foi a de esperançarmo-nos, resistindo! Freire consegue isso: a forma como tece e costura palavras, encharcadas na sua práxis, provoca certo tipo de reação nos leitores e ouvintes, pois ler Freire emociona e gratifica.

Foram cinco décadas de análises e críticas, traduções e reedições, e o reencontramos hoje, atualíssimo, pois as causas geradoras das desigualdades continuam a lançar seus dardos, e construir-se um educando ou cidadão crítico, requer leitura de mundo, pensar sobre si, sobre sua atuação, atitude nem sempre fácil de realizar, para gradativamente compreender a realidade cognoscível até chegar a uma posição epistemológica, como tão bem definiu Freire (1980).

Ao propor uma educação dialógica, pensa na construção de conhecimentos em conjunto, escapando da educação bancária, em que o professor desempenha o papel de transmissor de conhecimentos, e o educando, de depositário, condenado a um eterno silêncio. Pedagogia do Oprimido, publicado inicialmente no exílio, é um hino de louvor à educação libertadora, uma educação que desata as amarras da ingenuidade e conduz à conscientização. Em Primeiras Palavras, na Pedagogia do Oprimido, Freire (1983) se dirige aos esfarrapados do mundo, afirmando que, após a conscientização, ao descobrirem sua condição, os oprimidos unir-se-ão aos demais oprimidos, e com eles enfrentarão "situações limites", isto é, barreiras, que quando transpostas, revelarão o “inédito viável”, que está mais a frente. 


\section{Referências}

APPLE, Michael. A educação e os novos blocos hegemônicos. In: RODRIGUES, Alberto. Sociologia da Educação. 5. ed. Rio de Janeiro: DP\&A, 2004. p. 111-145.

BEISIEGEL, Celso de Rui. Paulo Freire. Recife: Fundação Joaquim Nabuco. Editora Massangana, 2010.

BETTO, Frei. O Que é Comunidade eclesial de Base. São Paulo: Brasiliense, 1981. Disponível em: http://www.estef.edu.br/zugno/wp-content/uploads/2011/05/cebsfreibetto.pdf. Acesso em 27 jun. 2019.

BOBBIO, Norberto; MATTEUCCI, Nicola; PASQUINO, Gianfranco. Dicionário de política. Brasília: Editora da Universidade de Brasília, 1998.

BRASIL. Lei no 6.683, de 28 de agosto de 1979. Concede anistia e dá outras providências, Brasília, DF, 28 ago. 1979. Disponível em: . Acesso em: 26 set. 2019.

CORTELLA, Mario S. Paulo Freire: Utopias e Esperança. In: GADOTTI, Moacir; CARNOY, Martin (orgs). Reinventando Freire: a práxis do Instituto Paulo Freire. São Paulo: Instituto Paulo Freire. Lemann Center/Stanford Graduate School of Education, 2018. p. 21-28.

FREIRE, Ana Maria. (org). Pedagogia dos Sonhos Possíveis. São Paulo: Editora UNESP, 2001.

FREIRE, Paulo. Experiência Revolucionária em Angicos e Natal: O povo aprende a ler debatendo problemas. - Entrevista ao Jornal Última Hora, 13/02/1963 - Acervo do Instituto Paulo Freire (09-0002), 1963.

FREIRE, Paulo. Educação como Prática da Liberdade. Rio de janeiro: Paz e Terra, 1967.

FREIRE, Paulo. Conscientização: teoria e prática da libertação. Uma introdução ao pensamento de Paulo Freire. São Paulo: Moraes, 1980.

FREIRE, Paulo. Pedagogia do Oprimido. Rio de Janeiro. Paz e Terra, 1983.

FREIRE, Paulo. A importância do ato de ler: três artigos que se completam. São Paulo: Cortez, 1989.

FREIRE, Paulo. Pedagogia da Esperança: um reencontro com a Pedagogia do Oprimido. Rio de Janeiro: Paz e Terra, 1993.

GERMANO, José. As Quarenta Horas de Angicos. Educação \& Sociedade, ano XVIII, ${ }^{\circ}$ 59, 1997.

MANNHEIM, Karl. Libertad y Planificación. México: Editora Fondo de Cultura Economica, 1942.

MOUNK, Yascha. O povo contra a democracia: por que nossa liberdade corre perigo e como salvá-la. São Paulo: Companhia das Letras, 2019. 
SILVA, Daniel Neves. "Revolução Cubana". Brasil Escola. Disponível em: https://brasilescola.uol.com.br/historiag/revolucao-cubana.htm. Acesso em: 05 de jul. de 2019.

VILLASANTE, Tomás. Estilos y epistemología en las metodologías participativas. In: FALCK, Andrés y YÁÑEZ, Pablo Paño. Democracia Participativa y Presupuestos participativos: acercamiento y profundización sobre el debate actual. Málaga, Espanha: Centro de Ediciones de La Diputación de Málaga, 2011.

VILLASANTE, Tomás. Desbordes Creativos. Estilos y estrategias para la transformación social. Catarata, Madrid, 2006.

VILLASANTE, Tomás, HERNÁNDEZ, Loli. Movimientos, Metodologías y Mediciones. In: RAMOS, Nara V., VILLASANTE, Tomás (orgs). Do Sul ao Norte, metodologias participativas desde a sociopráxis. São Borja, RS: Faith, 2015. 